\title{
Zoonotic pathogens associated with Hyalomma aegyptium in endangered tortoises: evidence for host-switching behaviour in ticks?
}

Anamaria I Paștiu', loana A Matei ${ }^{1}$, Andrei D Mihalca ${ }^{1 *}$, Gianluca D’Amico', Mirabela O Dumitrache', Zsuzsa Kalmár ${ }^{1}$, Attila D Sándor ${ }^{1}$, Menelaos Lefkaditis², Călin M Gherman ${ }^{1}$ and Vasile Cozma ${ }^{1}$

\begin{abstract}
Background: Hyalomma aegyptium is a hard-tick with a typical three-host life cycle. The main hosts are Palearctic tortoises of genus Testudo. However, other hosts can be used by immature ticks for feeding in natural conditions. Given this complex ecology and multiple host use, the circulation of pathogens by $\mathrm{H}$. aegyptium between various hosts can be important from epidemiological point of view. The aim of this study was to evaluate the role of H. aegyptium as natural carrier of four important zoonotic pathogens.
\end{abstract}

Methods: From 2008 to 2011, 448 H. aegyptium ticks were collected from 45 Spur-thighed tortoises, Testudo graeca in Romania. DNA was extracted individually from each tick using a commercial kit. DNA was examined for the presence of specific sequences of Borrelia burgdorferi s.l., Anaplasma phagocytophilum, Ehrlichia canis and Coxiella burnetii by PCR, according to previously described protocols.

Results: PCR analysis of H. aegyptium revealed the presence of A. phagocytophilum (18.8\%), E. canis (14.1\%) and C. burnetii (10\%). 32.4\% of the ticks were infected with at least one pathogen and $9.8 \%$ had co-infections. The stages most frequently infected were nymphs (50\%) followed by males (33.9\%) and females (27\%). The number of tortoises which harboured infected ticks was 27/45 examined (60\%). From all tested T. graeca, $40 \%$ harboured ticks infected with A. phagocytophilum, $46.7 \%$ had ticks infected with E. canis and $33.3 \%$ had ticks with C. burnetii. This study reports for the first time the presence of A. phagocytophilum and E. canis in H. aegyptium.

Conclusions: The presence and relatively high prevalence of three important zoonotic pathogens in $H$. aegyptium raises the question of their epidemiologic importance in disease ecology. As tortoises are unlikely to be reservoir hosts for A. phagocytophilum and E. canis and both these pathogens are common in H. aegyptium, this is an important indication for (1) a possible increased host-switching behaviour of these ticks to competent reservoir hosts (i.e. hedgehogs) and (2) transstadial transmission. Furthermore, if we consider also the presence of C. burnetii, we conclude that T. graeca and its ticks should be evaluated more seriously when assessing the eco-epidemiology of zoonotic diseases.

Keywords: Hyalomma aegyptium, Testudo graeca, Borrelia burgdorferi s.l, Anaplasma phagocytophilum, Ehrlichia canis, Coxiella burnetii

\footnotetext{
* Correspondence: amihalca@usamvcluj.ro

'Department of Parasitology and Parasitic Diseases, Faculty of Veterinary Medicine, University of Agricultural Sciences and Veterinary Medicine

Cluj-Napoca, Calea Mănăștur 3-5, Cluj-Napoca 400372, Romania

Full list of author information is available at the end of the article
} 


\section{Background}

Hyalomma aegyptium (Linnaeus, 1758) is a hard-tick with a typical three-host life cycle [1]. The main hosts for adults are Palearctic tortoises of the genus Testudo [2]. Hence, the distribution of this tick is restricted to the distribution of the principal hosts: Mediterranean bioregion from the Atlantic coastland of Morocco through Northern Africa, Balkan countries, Middle East, and Caucasus and steppic regions in Central Asia, Afghanistan, and Pakistan [3-5]. However, although rarely reported, other hosts (hedgehogs and hares) can be used by adults for feeding in natural conditions [6,7]. Nevertheless, larvae and nymphs of $H$. aegyptium are less host-specific and feed on various vertebrates: tortoises, lizards, birds, small mammals and even humans [1,8-10].

Given this complex ecology and multiple host use, the transmission of pathogens by $H$. aegyptium between reservoir hosts in natural cycles can be important from an epidemiological point of view. Determining the vectorial capacity of a tick to a certain pathogen is questionable if based only on pathogen detection (mainly by PCR), without experimental trials [11]. Several pathogens were detected in H. aegyptium: Theileria annulata [12], Borrelia turcica [13], Rickettsia spp. and Borrelia burgdorferi s.l. [14]. Experimental trials are usually long and difficult to perform, hence the need for a preliminary assessment of the carrier status in natural populations. Until now, experimental proof of the vectorial capacity of $H$. aegyptium was shown for several pathogens: Hemolivia mauritanica [15], Hepatozoon kisrae [16], Rickettsia aeschlimannii [17] and Coxiella burnetii [18].

In Romania, all stages of $H$. aegyptium were found on only two hosts, the Spur-thighed tortoise, Testudo graeca and the Northern White-breasted hedgehog, Erinaceus roumanicus and its distribution matches the one of the tortoise host [19]. Reptiles can serve as reservoirs for numerous important pathogens [20,21]. Particularly longliving tortoises could have a potential role in long-term maintenance of natural foci of infectious diseases and their ticks can serve as vectors [22,23]. Moreover, in the case of reptile ticks feeding occasionally on mammal hosts (i.e. in their larval and nymphal stage, as the case of $H$. aegyptium) studies regarding the presence of zoonotic agents are of particular interest because of the potential role of these ticks to maintain and cycle the pathogens in nature.

In Romania, there are few studies on the epidemiology and distribution of zoonotic tick-borne pathogens. In the same geographical area (Tulcea and Constanța County), Mircean et al. [24] reported dogs seropositive for $A$. phagocytophilum and E. canis and Majláthová et al. [21] found Ixodes ricinus ticks infected with Borrelia burgdorferi s.l. Moreover, $H$. aegyptium was shown to be a competent vector for $C$. burnetii under laboratory conditions but the natural role of this tick in the ecology of Q fever was never assessed. Hence, the aim of the present study was to evaluate the role of $H$. aegyptium as natural carrier of four important zoonotic pathogens: Borrelia burgdorferi sensu lato (s.l.), Anaplasma phagocytophilum, Ehrlichia canis and Coxiella burnetii.

\section{Methods}

\section{Sample collection and study area}

From 2008 to 2011, 448 engorged H. aegyptium ticks (2 larvae, 16 nymphs and 430 adults: 304 males and 126 females) were collected from Spur-thighed tortoises, Testudo graeca ibera (see Additional file 1 for details on collection sites). No other tick species were found. Tortoises were located and hand caught in their natural environment and released at the spot after tick collection. The animals were captured predominantly in the understory of sub-mediterranean xerophile oak-hornbeam (Quercus spp., Carpinus orientalis) forests (Figure 1, blue and purple spots) and dry steppe grasslands used as extensive pastures (Figure 1, red spots), with high turnover of small ruminant herding (sheep and goat). A total of 45 tortoises were collected, from 12 localities, all in Dobrogea, SE Romania. Collection was made in the active period of tortoises, from April to June. Individual tortoises were carefully inspected for ticks and all ticks were removed and collected in individual vials. Ticks were stored in ethanol at $-20^{\circ} \mathrm{C}$ until examination. Specific identification of ticks was performed using morphological keys [25] under a binocular microscope.

\section{DNA extraction and PCR amplification}

DNA was extracted individually from each tick using a commercial DNA extraction kit (DNeasy Blood \& Tissue Kit, Qiagen), according to the manufacturer's instructions. Extracted DNA was examined for the presence of specific sequences of B. burgdorferi s.l., A. phagocytophilum and $C$. burnetii by standard PCR and E. canis by nested PCR, with the primers shown in Table 1 , according to previously

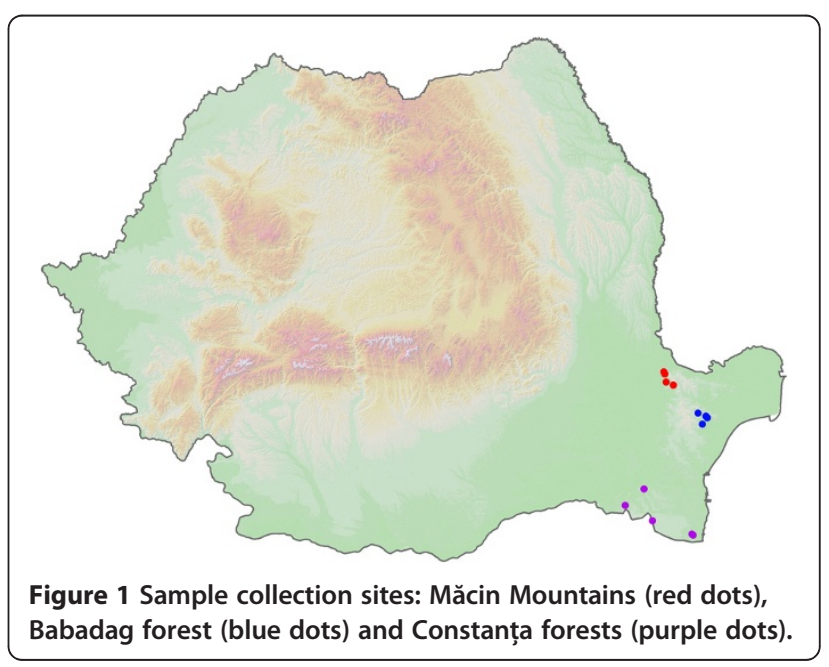


Table 1 Targeted genes and list of primers used in this study

\begin{tabular}{|c|c|c|c|c|c|}
\hline Pathogen & Gene & Primer sequence $\left(5^{\prime}-3^{\prime}\right)$ & $\begin{array}{l}\text { Size of PCR } \\
\text { product (bp) }\end{array}$ & Reference & Positive controls \\
\hline Borrelia burgdorferi s.l. & OspA & $\begin{array}{l}\text { GGG AAT AGG TCT AAT ATT AGC CCAC TAA TTG TTA AAG } \\
\text { TGG AAG T }\end{array}$ & $665 \mathrm{bp}$ & {$[26]$} & ATCC BG/N \\
\hline $\begin{array}{l}\text { Anaplasma } \\
\text { phagocytophilum }\end{array}$ & msp2 & $\begin{array}{l}\text { TTG GTC TTG AAG CGC TCG TAATG GAA GGT AGT GTT } \\
\text { GGT TAT GGT ATT }\end{array}$ & $420 \mathrm{bp}$ & {$[27]$} & $\begin{array}{l}\text { A. phagocytophilum } \\
\text { (dog isolate) }\end{array}$ \\
\hline \multirow[t]{2}{*}{ Ehrlichia canis } & $\begin{array}{l}16 S \\
\text { rRNA }\end{array}$ & $\begin{array}{l}\text { Ehrlichia spp.AGA ACG AAC GCT GGC GGC AAG CCCGT } \\
\text { ATT ACC GCG GCT GCT GGC }\end{array}$ & $478 \mathrm{bp}$ & [29] & E. canis (dog isolate) \\
\hline & & $\begin{array}{l}\text { Ehrlichia canis CAA TTA TाT ATA GCC TCT GGC TAT AGCTAT } \\
\text { AGG TAC CGT CAT TAT CTT CCC TAT }\end{array}$ & $389 \mathrm{bp}$ & & \\
\hline Coxiella burnetii & IS1111 & $\begin{array}{l}\text { CTC GTA ATC ACC AAT CGC TTC GCAA GAA TGA TCG TAA } \\
\text { CGA TGC GC }\end{array}$ & $337 \mathrm{bp}$ & {$[28]$} & $\begin{array}{l}10^{5} \text { C. burnetii/ml } \\
\text { (culture) }\end{array}$ \\
\hline
\end{tabular}

described protocols [26-29]. The amplification was performed in Bio-Rad $\mathrm{C} 1000^{\mathrm{TM}}$ Thermal Cycler. Aliquots of each PCR product were electrophoresed on 1.5\% agarose gel stained with SYBR $^{\circledR}$ Safe DNA gel stain (Invitrogen) and examined for the presence of the specific fragment under UV light (Bio-Rad BioDoc-It ${ }^{\mathrm{TM}}$ Imagine System). DNA fragment size was compared with a standard molecular weight, 100 bp DNA ladder (Fermentas). Distilled water was used as negative control.

\section{Statistical analysis}

Frequency, prevalence and its 95\% confidence interval of $B$. burgdorferi s.l, $A$. phagocytophilum, E. canis and C. burnetii DNA and respective co-infections in $H$. aegyptium were established. These parameters were determined according to sex and developmental stage of the ticks (males, females, nymphs and larvae) and geographic location. The difference of prevalence among groups was statistically analysed by chi-squared independence. A $p$ value of $<0.05$ was statistically significant. All statistical analyses were performed using the EpiInfo 2000 software.

\section{Results}

PCR analysis of $H$. aegyptium revealed the presence of three pathogens (A. phagocytophilum, E. canis and C. burnetii) from the four tested (no samples were positive for $B$. burgdorferi s.l.). From the total number of ticks examined, 145 were infected with at least one pathogen (32.4\%; 145/448; CI 95\%: 28.1-36.9). The frequency and prevalence of each detected pathogen are shown in Table 2. The highest molecular prevalence was detected for A. phagocytophilum (18.8\%), followed by E. canis (14.1\%) and C. burnetii (10\%). The developmental stages most frequently infected with at least one pathogen were nymphs (50\%; 8/16; CI 95\%: 24.7-75.3) followed by adult males (33.9\%; 103/304; CI 95\%: 28.6-39.5) and females (27\%; 34/126; CI 95\%: 19.5-35.6).

The prevalence of the co-infections was $9.8 \%(44 / 448$; CI 95\%: 7.3-13.1). The prevalence of co-infections was higher in nymphs $(12.5 \% ; 2 / 16$; CI 95\%: 1.6-38.3) and males (12.2\%; 37/304; CI95\%: 8.8-16.5) than in other developmental stages $(p<0.00001)$. The only region where co-infected ticks were found was Măcin Mountains, with $10.9 \%$ from the total number of ticks (36/330; CI 95\%: 7.9-14.9). The most frequent co-infection type was A. phagocytophilum-E. canis (43.2\%; 19/44; CI 95\%: 28.3-59.0), followed by A. phagocytophilum-C. burnetii (38.6\%; 17/44, CI 95\%: 24.4-54.5).

The number of tortoises which harboured infected ticks (regardless the pathogen) was 27 out of 45 examined (60\%; CI 95\%: 44.3-74.3). From all tested T. graeca, 18 (40\%) harboured ticks infected with $A$. phagocytophilum, 21 (46.7\%) had ticks infected with E. canis and 15 (33.3\%) had ticks with $C$. burnetii. Interestingly, from the 27

Table 2 Prevalence of A. phagocytophilum, E. canis and C. burnetii DNA in H. aegyptium collected from $T$. graeca

\begin{tabular}{|c|c|c|c|c|c|c|}
\hline & \multicolumn{2}{|c|}{ Anaplasma phagocytophilum } & \multicolumn{2}{|c|}{ Ehrlichia canis } & \multicolumn{2}{|c|}{ Coxiella burnetii } \\
\hline & PCR positives/all tested & $\begin{array}{l}\text { Prevalence \% } \\
\text { (Cl 95\%) }\end{array}$ & PCR positives/all tested & $\begin{array}{l}\text { Prevalence \% } \\
\text { (Cl 95\%) }\end{array}$ & PCR positives/all tested & $\begin{array}{l}\text { Prevalence \% } \\
\text { (CI 95\%) } \\
\end{array}$ \\
\hline Larvae & $0 / 2$ & $0(0.0-84.2)$ & $0 / 2$ & $0(0.0-84.2)$ & $0 / 2$ & $0(0.0-84.2)$ \\
\hline Nymphs & $8 / 16$ & $50(24.7-75.3)$ & $0 / 16$ & $0(0.0-20.6)$ & $2 / 16$ & $12.5(1.6-38.3)$ \\
\hline Females & $0 / 126$ & $0(0.0-2.9)$ & $20 / 126$ & $15.9(10.0-23.4)$ & $19 / 126$ & $15.1(9.3-22.5)$ \\
\hline Males & $76 / 304$ & $25(20.3-30.3)$ & $43 / 304$ & $14.1(10.5-18.7)$ & $24 / 304$ & $7.9(5.2-11.7)$ \\
\hline TOTAL & $84 / 448$ & $18.8(15.3-22.7)$ & $63 / 448$ & $14.1(11.0-17.7)$ & $45 / 448$ & $10(7.5-13.3)$ \\
\hline
\end{tabular}


tortoises which harboured infected ticks, 18 had ticks infected independently or co-infected with at least two pathogens (Table 3).

\section{Discussion}

Ticks are vectors of important pathogens of humans and animals and serve as indicators of infection in nature [30]. The geographical distribution and habitats of several generalist tick species have expanded in the recent years. Major drivers for this trend include land use, climate changes and globalization [31,32]. On the other hand, for certain tick species which are co-distributed with their endangered hosts, like the case of $H$. aegyptium, the trend is a decreasing geographical range [2]. However, in general, a decrease in the availability of natural host populations could lead to host-switching behaviour [33]. As $H$. aegyptium is reported to alternatively feed on various other hosts, mainly during their pre-imaginal stages, evaluation of its zoonotic pathogen burden is of particular interest.

Regarding their role in the ecology of zoonotic infectious diseases, tortoises and their ticks have received significantly less attention compared to mammals and birds. Among small mammals, hedgehogs (Erinaceus spp.) are important mainly in synanthropic environments as reservoir hosts for important human pathogens like A. phagocytophilum, Babesia spp. [34] or B. burgdorferi s.l. [35]. As H. aegyptium occasionally feeds on hedgehogs and it can potentially attack humans [10], the evaluation of this species as a carrier host for zoonotic pathogens is important.

For B. burgdorferi s.l., the main vectors are ticks of genus Ixodes and the reservoir hosts, mostly small mammals [36]. Although in this survey there were no $H$. aegyptium positive for the Lyme disease agent, some other studies reported that this tick can feed on reservoir hosts of Borrelia lusitaniae [37]. The role of reptiles in the ecology of B. lusitaniae was shown in the past by several authors [38,39]. Borrelia burgdorferi s.l. is one of the most extensively studied tick-borne pathogens in the world. Hence, there were numerous experimental trials for assessing the vectorial capacity of various ticks. So far, experimental data suggest that only ticks of genus Ixodes are competent vectors for the Lyme disease spirochetes [40]. However, Kar et al. [14] found B. burgdorferi s.l. in two out of 28 pools of $H$. aegyptium collected from Testudo graeca in Turkey. In the present study no ticks were positive for this pathogen, supporting the

Table 3 Number of Testudo graeca which harboured ticks infected with pathogens (independent infection of ticks with one or more pathogens, but on the same host)

\begin{tabular}{lcccccccc}
\hline Pathogens & A & E & C & A-E & A-C & C-E & A-E-C & Negative \\
\hline No. tortoises & 3 & 6 & 0 & 4 & 3 & 3 & 8 & 18
\end{tabular}

Legend: A - Anaplasma phagocytophilum; E - Ehrlichia canis; C - Coxiella burnetii. hypothesis that ticks other than Ixodes spp. should not be assumed to serve as bridging vectors for B. burgdorferi s.l. or to play any role in the maintenance of these spirochetes in natural cycles [40].

Anaplasma phagocytophilum, the agent of human granulocytic anaplasmosis, is vectored in Europe by Ixodes ricinus and can infect a wide range of domestic and wild vertebrate hosts, including rodents, horses, dogs and humans [41]. This is the first report of $A$. phagocytophilum in $H$. aegyptium ticks. The relatively high prevalence of $A$. phagocytophilum in this study (18.8\%) in fully engorged $H$. aegyptium collected from tortoises can be theoretically caused by two factors: (1) the infection was acquired by ticks during an earlier developmental stage feeding on competent reservoir hosts or (2) tortoises are competent reservoir hosts. The second hypothesis is less probable, as several studies showed that reptiles are not competent reservoir hosts for this pathogen $[42,43]$. Moreover, surveillance of other ticks parasitic on reptiles yielded negative results [44]. Prevalence of Anaplasma spp. in engorged Hyalomma lusitanicum and $H$. marginatum collected on domestic mammals in Sicily was much lower $(\sim 1 \%)$ [45]. All these data (improbable reservoir role of tortoises and relatively high prevalence), suggest that $H$. aegyptium is able to transstadially pass in A. phagocytophilum. However, the probable lack of transovarial transmission of $A$. phagocytophilum in ticks [46] confers little eco-epidemiological importance to this vector-pathogen association.

The genus Ehrlichia includes five species [47], but only E. canis is found in Europe. This study reports the presence of $E$. canis for the first time in $H$. aegyptium, with a noteworthy prevalence. The only recognized vector for $E$. canis is Rhipicephalus sanguineus. In Romania, the distribution range of $H$. aegyptium overlaps with the distribution of $R$. sanguineus [19]. Although R. sanguineus feeds mainly on dogs [48], in Romania, it has been found also on hedgehogs (E. roumanicus) [19]. This is indicative of a possible cross transmission of $E$. canis from $R$. sanguineus to $H$. aegyptium using hedgehogs as bridging hosts.

The Q fever agent, C. burnetii was present only in Măcin Mountains with a relatively high prevalence in ticks (37.9\%). An interesting aspect in this area was that all tortoises harbouring $C$. burnetii-infected ticks had also $A$. phagocytophilum-infected ticks and $72.7 \%$ of these tortoises had ticks infected with $E$. canis, too. Additionally, out of the 11 tortoises infested with C. burnetii-infected ticks, 10 (90.9\%) had co-infected ticks. Q fever affects a wide range of domestic and free living mammals, birds, reptiles, fish, and arthropods, as well as humans $[49,50]$. The etiological agent of Q fever, C. burnetii, has been identified in over 40 tick species [50,51]. Hyalomma aegyptium was shown to have an unquestionable potential in the epidemiology of $\mathrm{Q}$ fever natural foci [18]. Ticks transmit $C$. burnetii vertically (transstadially and transovarially) and 
horizontally (by biting, via saliva) [52] but also through their faeces [53]. Sharing of pastures by tortoises and domestic ruminants was suggested by Široký et al. [18] to have an important role in the natural cycle, especially if considering that tortoises maintain natural foci of $\mathrm{Q}$ fever by hosting long-term infected ticks [18].

We found a marked dissimilarity between the occurrences of individual pathogens in ticks among the different locations: Anaplasma phagocytophilum and E. canis being found in all three locations while C. burnetii was only present in one. This variance may be caused by the different habitat associations and its host-fauna composition. The two forested sample sites have high occurrence rates of small mammals, especially hedgehogs, while the third location is primarily used by small domestic ruminants [54]. Coxiella burnetii is commonly reported in sheep and goats [55], hence its occurrence is more likely in the later habitat. This is consistent with the present findings. Moreover, the local agricultural practice (i.e. high turnover rate of domestic herds on extensive used pastures) in this region provides chances for a continuous presence of this pathogen in the environment [56].

\section{Conclusions}

The presence and relatively high prevalence of three important zoonotic pathogens in $H$. aegyptium raises the question of their epidemiologic importance in disease ecology. As tortoises are unlikely reservoir hosts for $A$. phagocytophilum and E. canis and both these pathogens are common in $H$. aegyptium, this is an important indication for (1) a possible increased host-switching behaviour of these ticks to competent reservoir hosts (i.e. hedgehogs) and (2) transstadial transmission. Furthermore, if considering also the presence of C. burnetii, it can be concluded that $T$. graeca and its ticks should be evaluated more seriously when assessing the eco-epidemiology of zoonotic diseases.

\section{Additional file}

Additional file 1: Origin of samples of Hyalomma aegyptium used in this study.

\section{Competing interests}

All authors have seen and approved the manuscript and declare that they have no competing interest.

\section{Authors' contributions}

PAI wrote the manuscript and made the statistical analysis; MIA and DMO identified the ticks; PAI, MIA and KZ performed the DNA extraction and PCR; MAD study design, MS concept and wrote the discussion, MAD, DG and SAD collected the samples; LM performed DNA extraction; GCM research project coordinator; CV team coordinator. All authors read and approved the final manuscript.

\section{Acknowledgments}

The publication of this paper was supported from grant IDEI-PCCE CNCSIS $84,7 / 2010$. We also want to thank the Administration of Măcin Mountains Natural Park for issuing the research permits. We are indebted to Cristian Domşa for creating the map. Special thanks to Nikola Pantchev (IDEXX Vet Med Labor, Germany) for providing positive controls of A. phagocytophilum and E. canis.

\section{Author details}

'Department of Parasitology and Parasitic Diseases, Faculty of Veterinary Medicine, University of Agricultural Sciences and Veterinary Medicine Cluj-Napoca, Calea Mănăștur 3-5, Cluj-Napoca 400372, Romania. ${ }^{2}$ Department of Microbiology and Parasitology, Faculty of Veterinary Medicine, University of Thessaly, Trikalon 224, PO Box 199, Karditsa 43100, Greece.

Received: 15 November 2012 Accepted: 23 December 2012

Published: 28 December 2012

\section{References}

1. Apanaskevich DA: Host-parasite relationships of the genus Hyalomma Koch (Acari, Ixodidae) and their connection with microevolutionary processes. Parazitologiya 2004, 38:515-523. in Russian.

2. Mihalca AD, Gherman CM, Cozma V: Coendangered hard-ticks: threatened or threatening? Parasit Vectors 2011, 4:71.

3. Kolonin GV: Mirovoe rasprostranenie iksodovykh kleshchey. Rody Hyalomma, Aponomma, Amblyomma [World distribution of ixodid ticks. Genera Hyalomma, Aponomma, Amblyomma]. Moskva, SSSR: Nauka; 1983. in Russian.

4. Apanaskevich DA: K diagnostike vida Hyalomma (Hyalomma) aegyptium (Acari, Ixodidae) [To diagnostics of Hyalomma (Hyalomma) aegyptium (Acari: Ixodidae)]. Parazitologiya 2003, 37:47-59. in Russian.

5. Široký P, Petrželková KJ, Kamler M, Mihalca AD, Modrý D: Hyalomma aegyptium as dominant tick in tortoises of the genus Testudo in Balkan countries, with notes on its host preferences. Exp Appl Acarol 2006, 40:279-290.

6. Hoogstraal H: African Ixodoidea. I. Ticks of the Sudan. Washington, DC, USA: Department of the navy, bureau of medicine and surgery; 1956.

7. Hoogstraal H, Kaiser MN: Some host relationships of the tortoise tick. Hyalomma (Hyalommasta) aegyptium (L.) (Ixodoidea, Ixodidae) in Turkey. Ann Entomol Soc Am 1960, 53:457-458.

8. Kolonin GV: Reptiles as hosts of ticks. Russ J Herp 2004, 11:177-180.

9. Vatansever Z, Gargili A, Aysul NS, Sengoz G, Estrada-Peña A: Ticks biting humans in the urban area of Istanbul. Parasitol Res 2008, 102:551-553.

10. Bursali A, Tekin S, Orhan M, Keskin A, Ozkan M: Ixodid ticks (Acari: Ixodidae) infesting humans in Tokat Province of Turkey: species diversity and seasonal activity. J Vector Ecol 2010, 35:180-186.

11. De Sousa R, Lopes De Carvalho I, Santos AS, Bernardes C, Milhano N, Jesus J, Menezes D, Núncio MS: Role of the lizard Teira dugesii as a potential host for Ixodes ricinus tick-borne pathogens. Appl Environ Microbiol 2012, 78:3767-3769.

12. Ray HN: Hereditary transmission of Theileria annulata infection in the tick, Hyalomma aegyptium Neum. Trans R Soc Trop Med Hyg 1950, 44:93-104.

13. Güner ES, Watanabe M, Hashimoto N, Kadosaka T, Kawamura Y, Ezaki T, Kawabata H, Imai Y, Kaneda K, Masuzawa T: Borrelia turcica sp. nov., isolated from the hard tick Hyalomma aegyptium in Turkey. Int I Sys Evol Micr 2004, 54:1649-1652.

14. Kar S, YIlmazer N, Midilli K, Ergin S, Alp H, Gargllı A: Presence of the zoonotic Borrelia burgdorferi s.l. and Rickettsia spp. in the ticks from wild tortoises and hedgehogs. J Marmara Univ Inst Health Sci 2011, 1:166-170.

15. Sergent ED, Sergent ET: Sur une hémogrégarine, parasite de Testudo mauritanica. C R Soc Biol 1904, 56:130-131.

16. Paperna I, Kremer-Mecabell T, Finkelman S: Hepatozoon kisrae n. sp. infecting the lizard Agama stellio is transmitted by the tick Hyalomma cf. aegyptium. Parasite 2002, 9:17-27.

17. Bitam I, Kernif T, Harrat Z, Parola P, Raoult D: First detection of Rickettsia aeschlimannii in Hyalomma aegyptium from Algeria. Clin Microbiol Infect 2009, 15:253-254.

18. Široký P, Kubelová M, Modrý D, Erhart J, Literák I, Špitalská E, Kocianová E: Tortoise tick Hyalomma aegyptium as long term carrier of $\mathrm{Q}$ fever agent 
Coxiella burnetii - evidence from experimental infection. Parasitol Res 2010, 107:1515-1520.

19. Mihalca AD, Dumitrache MO, Magdaş C, Gherman CM, Domşa C, Mircean V, Ghira IV, Pocora V, Ionescu DT, Sikó Barabási S, Cozma V, Sándor AD: Synopsis of the hard ticks (Acari: Ixodidae) of Romania with update on host associations and geographical distribution. Exp Appl Acarol 2012, 58:183-206

20. Yadav MP, Sethi MS: Poikilotherms as reservoirs of Q-fever (Coxiella burnetii) in Uttar Pradesh. J Wildl Dis 1979, 15:15-17.

21. Majláthová V, Majláth I, Hromada M, Tryjanowski P, Bona M, Antczak M, Víchová B, Dzimko S, Mihalca A, Pet'ko B: The role of the sand lizard (Lacerta agilis) in the transmission cycle of Borrelia burgdorferi sensu lato. Int J Med Microbiol 2008, 298:161-167.

22. Peter TF, Burridge MJ, Mahan SM: Competence of the African tortoise tick, Amblyomma marmoreum (Acari: Ixodidae), as a vector of the agent of heartwater (Cowdria ruminantium). J Parasitol 2000, 86:438-441.

23. Široký P, Kamler M, Modry D: Long-term occurrence of Hemolivia cf. mauritanica (Apicomplexa: Adeleina: Haemogregarinidae) in captive Testudo marginata (Reptilia: Testudinidae): Evidence for cyclic merogony? J Parasitol 2004, 90:1391-1393.

24. Mircean V, Dumitrache MO, Györke A, Pantchev N, Jodies R, Mihalca AD, Cozma V: Seroprevalence and geographic distribution of Dirofilaria immitis and tick-borne infections (Anaplasma phagocytophilum, Borrelia burgdorferi sensu lato, and Ehrlichia canis) in dogs from Romania. Vector Borne Zoonotic Dis 2012, 12:595-604.

25. Feider Z: Fauna RPR. Arachnida. Vol V. Fasc 2. Bucureşti: Academiei RPR 1965. in Romanian

26. Pleyer U, Priem S, Bergmann L, Burmester G, Hartmann C, Krause A: Detection of Borrelia burgdorferi DNA in urine of patients with ocular Lyme borreliosis. Br J Ophthalmol 2001, 85:552-555.

27. Courtney JW, Kostelnik LM, Zeidner NS, Massung RF: Multiplex Real-Time PCR for Detection of Anaplasma phagocytophilum and Borrelia burgdorferi. J Clin Microbiol 2004, 42:3164-3168.

28. Alsaleh A, Pellerin JL, Rodolakis A, Larrat M, Cochonneau D, Bruyas JF, Fien F: Detection of Coxiella burnetii, the agent of $\mathrm{Q}$ fever, in oviducts and uterine flushing media and in genital tract tissues of the non pregnant goat. Comp Immunol Microb 2011, 34:355-360.

29. Rotondano TE, de Almeida AM, Lustosa EM, Cordeiro AA, Camboim EK, de Azvedo SS, de Andrade PP, de Melo MA: An assessment of whole blood and fractions by nested PCR as a DNA source for diagnosing canine ehrlichiosis and anaplasmosis. Scientific World Journal 2012, 2012:605743.

30. Rizzoli A, Hauffe HC, Carpi G, Vourc'h Gl, Rosa R, Neteler M: Lyme borreliosis in Europe. Euro Surveill 2011, 16:1-8.

31. Gubler DJ, Reiter P, Ebi KL, Yap W, Nasci R, Patz JA: Climate variability and change in the United States: potential impacts on vector and rodentborne diseases. Environ Health Perspect 2001, 109:223-233.

32. Harrus S, Baneth $\mathrm{G}$ : Drivers for the emergence and re-emergence of vector-borne protozoal and bacterial diseases. Int J Parasitol 2005, 35:1309-1318.

33. Keesing F, Belden LK, Daszak P, Dobson A, Harvell CD, Holt RD, Hudson P, Jolles A, Jones KE, Mitchell CE, Myers SS, Bogich T, Ostfeld RS: Impacts of biodiversity on the emergence and transmission of infectious diseases. Nature 2010, 468:647-652.

34. Silaghi C, Woll D, Hamel D, Pfister K, Mahling M, Pfeffer M: Babesia spp. and Anaplasma phagocytophilum in questing ticks, ticks parasitizing rodents and the parasitized rodents - Analyzing the host-pathogen-vector interface in a metropolitan area. Parasit Vectors 2012, 5:191.

35. Skuballa J, Petney T, Pfäffle M, Oehme R, Hartelt K, Fingerle V, Kimmig P, Taraschewski H: Occurrence of different Borrelia burgdorferi sensu lato genospecies including $B$. afzelii, B. bavariensis, and B. spielmanii in hedgehogs (Erinaceus spp.) in Europe. Ticks Tick Borne Dis 2012, 3:8-13.

36. Jaenson TGT, Hjertqvist M, Bergström T, Lundkvist $\AA$ : Why is tick-borne encephalitis increasing? A review of the key factors causing the increasing incidence of human TBE in Sweden. Parasit Vectors 2012, 5:184.

37. De Michelis S, Sewell HS, Collares-Pereira M, Santos-Reis M, Schouls LM, Benes V, Holmes EC, Kurtenbach K: Genetic diversity of Borrelia burgdorferi sensu lato in ticks from mainland Portugal. J Clin Microbiol 2000, 38:2128-2133.

38. Ekner A, Dudek K, Sajkowska Z, Majláthová V, Majláth I, Tryjanowski P: Anaplasmataceae and Borrelia burgdorferi sensu lato in the sand lizard
Lacerta agilis and co-infection of these bacteria in hosted Ixodes ricinus ticks. Parasit Vectors 2011, 4:182.

39. Tijsse-Klasen E, Fonville M, Reimerink JHJ, van der Sluijs Spitzen A, Sprong H: Role of sand lizards in the ecology of Lyme and other tick-borne diseases in the Netherlands. Parasit Vectors 2010, 3:42.

40. Eisen L, Lane RS: Vectors of Borrelia burgdorferi sensu lato. In Lyme Borreliosis: Biology, Epidemiology and Control. Wallingford, Oxon, UK: CABI Publishing; 2002:91-115.

41. Alleman AR, Wamsley HL: An update on anaplasmosis in dogs. Vet Med 2008, 103:212-220

42. Smrdel KS, Serdt M, Duh D, Knap N, Zupanc TA: Anaplasma phagocytophilum in ticks in Slovenia. Parasit Vectors 2010, 3:102.

43. Nieto NC, Foley JE, Bettaso J, Lane RS: Reptile infection with Anaplasma phagocytophilum, the causative agent of granulocytic anaplasmosis. J Parasitol 2009, 95:1165-1170.

44. Nowak M, Cieniuch S, Stańczak J, Siuda K: Detection of Anaplasma phagocytophilum in Amblyomma flavomaculatum ticks (Acari: Ixodidae) collected from lizard Varanus exanthematicus imported to Poland. Exp Appl Acarol 2010, 51:363-371.

45. Torina A, Alongi A, Scimeca S, Vicente J, Caracappa S, de la Fuente J: Prevalence of tick-borne pathogens in ticks in Sicily. Transbound Emerg Dis 2010, 57:46-48.

46. Severinsson K, Jaenson TG, Pettersson J, Falk K, Nilsson K: Detection and prevalence of Anaplasma phagocytophilum and Rickettsia helvetica in Ixodes ricinus ticks in seven study areas in Sweden. Parasit Vectors 2010, 3:66.

47. Rikihisa Y: The tribe Ehrlichieae and ehrlichial diseases. Clin Microbiol Rev 1991, 4:286-308.

48. Torres FD: Biology and ecology of the brown dog tick, Rhipicephalus sanguineus. Parasit Vectors 2010, 3:26.

49. Maurin M, Raoult D: Q fever. Clin Microbiol Rev 1999, 12:518-553.

50. Kazar J: Coxiella burnetii infection. Ann N Y Acad Sci 2005, 1063:105-114

51. Psaroulaki A, Ragiadakou D, Kouris G, Papadopoulos B, Chaniotis B, Tselentis Y: Ticks, tick-borne Rickettsiae, and Coxiella burnetii in the Greek Island of Cephalonia. Ann N Y Acad Sci 2006, 1078:389-399.

52. Řeháček J, Brezina R: Detection of Coxiella burnetii in saliva of experimentally infected ticks, Hyalomma dromedarii Koch. Bull World Health Organ 1968, 39:974-977.

53. Hirai $\mathrm{K}, \mathrm{To} \mathrm{H}$ : Advances in the understanding of Coxiella burnetii infection in Japan. J Vet Med Sci 1998, 60:781-790.

54. Murariu D: Mammal ecology and distribution from North Dobrogea (Romania). Travaux du Muséum National d'Histoire Naturelle "Grigore Antipa» 2006, 49:387-399.

55. Van den Brom R, Moll L, van Schaik G, Vellema P: Demography of Q fever seroprevalence in sheep and goats in The Netherlands in 2008. Prev Vet Med, . in press.

56. Ardeleanu D, Neacşu GM, Pivoda CA, Enciu A: Poliparasitism structure in small ruminants in Dobrogea. Bull Univ Agri Sci Vet Med, Vet Med Book Ser 2003, 60:28-32. in Romanian.

doi:10.1186/1756-3305-5-301

Cite this article as: Paștiu et al:: Zoonotic pathogens associated with Hyalomma aegyptium in endangered tortoises: evidence for hostswitching behaviour in ticks?. Parasites \& Vectors 2012 5:301.

\section{Submit your next manuscript to BioMed Central and take full advantage of:}

- Convenient online submission

- Thorough peer review

- No space constraints or color figure charges

- Immediate publication on acceptance

- Inclusion in PubMed, CAS, Scopus and Google Scholar

- Research which is freely available for redistribution 